\title{
AZ EGYÜTTMÜKÖDÉS HIÁNYA: A HAZAI TERMÉSZETTUDOMÁNYI TANÁRKÉPZÉS CSŐDJE
}

\author{
PATKós ANDRÁs \\ az Eötvös Loránd Tudományegyetem Természettudományi Karának \\ egyetemi tanára \\ patkos@hector.elte.hu
}

\section{Az ELTE Bolyai Kollégium Baráti Köréről és a Bolyai Mühelykonferenciákról}

Elképzelem a Tanárképzők Akadémiája szervezőinek zavarát, amikor az MTA Oktatási Stratégiai munkacsoportja elnöke és a Köztársasági Elnök által felkért Bölcsek Tanácsának tagja mellett megszólalásra invitált harmadik személynek keresték a titulusát. Nehéz lehetett megindokolni egy baráti kör, senki által semmilyen hivatalos szerepre fel nem kért koordinátorának meghívását.

Az ELTE Bolyai Kollégiuma az École Normale Supérieure és az angliai Oxbridge kollégiumainak mintáját követve készíti fel az ELTE TTK és IK legtörekvőbb hallgatóit a természettudományi kutatómunkára. Szakmai támogatásukra az ügy iránt fellobbanó lelkesedésű TTK-s professzorokból, továbbá néhány külső tagból szervezte meg Kondor Imre alapító igazgató 1994-ben a Bolyai Kollégium Baráti Körét.

Ez a Kör a kollégium normális müködése esetén csendes unalomba süppedt volna. Azonban 2004-ben az ELTE akkori rektora túl nagy fényüzésnek minősítette a kollégisták kétágyas elhelyezését, a színvonalas számítógépszobát, a nevelőtanárok helyett alkalmazott (általában MTA-doktori címmel rendelkező) szemináriumvezető tanárokat és sok egyebet is, amit szokás besorolni az „elitizmus bünlajstromába". Kezdeményezte a Bolyai Kollégium önállóságának megszüntetését és ezzel életre keltette a tetszhalott Baráti Kört.

2004-től kezdve előbb kényszerszülte kollégiumigazgatóként, majd 2007 óta a Bolyai Kollégium Baráti Köre elnökeként féléves rendszerességü összejövetelre „kényszerítem” tagjainkat, hogy se ők, se a kívülállók ne feledkezhessenek meg létezésünkről. Létrehoztuk Ifjúsági Szekciónkat a volt kollégisták közül tudományos fokozatot szerzettek számára. Ők és szemináriumvezető tanáraink adják a kollégium szakmai profiljának jövőbeli alakulását meghatározó új generációt.

A Baráti Kör félévenkénti összejöveteleinek témái kezdettől fogva túllépnek a Bolyai Kollégium igazgatója beszámolóin. A kollégiumhoz kötődő események elválaszthatatlanok a természettudományok hazai helyzetétől. 2007 nyarán vetettem fel néhány kollégámnak e rövid beszélgetések önállósításának gondolatát. 
A Bolyai Mühelykonferenciák három éve tartó sorozata félévenként a résztvevők egy-egy szombatjára tart igényt. A müszaki és a természettudományok közoktatási háttere (PISA-TIMMS), az alap- és mesterképzési szakaszra felbontott felsőoktatási rendszer és a kutatóegyetemi minőség szerepeltek az eddigi hat összejövetel vitatémái között. Az oktatással foglalkozó megbeszéléseinken rendszeresen részt vesznek egyetemi hallgatók és középiskolai tanárok is.

A Mühelykonferenciák föként a résztvevők gondolkodásának összehangolása révén fejtik ki hatásukat. Az összefoglalók szövegét a résztvevők közötti 8-10 napos körözés és általában nagyszámú hozzászólás után véglegesítjük. A gondolkodás összhangja révén terjedt el országosan az elsőéves TTK-s és müszakis hallgatók középiskolai tudását fizikából, matematikából felmérő dolgozatok megíratása, majd ezek eredményei alapján a középiskolai ismeretek felzárkóztató kurzusai. Örülök, hogy a mühelykonferenciákon résztvevők közvetítésével megállapításainkat megismerték a témával foglalkozó más testületek is. Írásos reflexiókat nem várunk, de azokat is elviseljük. Jobban örülünk, ha összejöveteleinkhez olvasóik közül új résztvevők csatlakoznak.

A mühelykonferencia müködtetésében kezdettől fogva törekszem a szervezésben elkötelezett kollégáknak az összes felsőoktatási intézményt átfogó körére, bármely kérdésben az eltérő vélemények kifejtésére és az összefoglalókban való megjelenítésükre. Nem tartom magam a vitatott kérdések szakértőjének, a „hátsó szándékom" az, hogy a hozzáértők ismerjék fel e fórumnak értékét és a szakmai közösség hiteles megnyilvánulásaként várják ezeket az összejöveteleket.

A Tanárképzők Akadémiájától kapott felkérést e szándék szerény sikereként értékeltem. A Bolyai Mühelykonferenciák hivatalos véleményét nem képviselhetem, mert olyan nincs. Személyes véleményemet mondhatom el a természettudományi tanári pálya gondjairól, kifejezve a Bolyai Mühelykonferenciák egy figyelmes hallgatójának élményeit.

\section{A természettudományi tanárok képzésének két peremfeltétele}

(A természetvizsgálók 170 éves szakmai közössége; Honnét az ösztönzés a természettudományok tanítására?)

A természettudományok kutatásával foglalkozók szerveződései fokozatosan differenciálódtak. A reáliákkal foglalkozó tanárok, kutatók és gyakorlati szakemberek első társaságát Bugát Pál alapította [Magyar Orvosok és Természetvizsgálók Társasága (1841)]. Ebből önállósodott a Természettudományi Társulat. Eötvös Loránd 1892-ben alapította a Mathematikai és Physikai Társulatot. 1949. óta önálló tudományos társaságként múködik a Bolyai János Matematikai Társaság és az Eötvös Loránd Fizikai Társulat.

E változások során változatlan, hogy a fizika vagy a matematika tanárai továbbra is ugyanazzal a szakmai közösséggel azonosultak, nem hoztak létre önálló 
tanári szervezetet. A BJMT szervezete egy-egy titkár által koordinált tanári és nemtanári szakosztályra bomlik, de egységes a Társaság vezetése és számos eseménye szintjén. Az ELFT számos szakcsoportja sorában egy középiskolai és egy általános iskolai szakcsoport müködik önállóan. A Társulat mindig ügyel elnökségében a tanári jelenlét erősségére. Mindkét társaság tagságának nagyjából fele tanár.

A szaktanárok elismerésében legmagasabb rangja a szakmai társulatok díjainak van (Beke Manó díj, Mikola Sándor díj). A Társulatok vonzáskörében nevelkedett vállalkozók alapították meg az Ericsson-dijakat és a Rátz-tanár-úr díjat. Ezeknek szakmai elismertsége meghaladja bármely, tanári munkáért elnyerhető állami kitüntetését.

Minden újítás a pedagógiai szervezetben vagy a szaktanárképzésben, amely ezt a beágyazottságot nem veszi figyelembe, netán meg akarja szüntetni, konfliktusokat szül és végül vereséget szenved, szándékaitól függetlenül.

Ez egy alapvető peremfeltétel, amelyet a tanárképzés átalakításának elmúlt időszakbeli irányítói hibás helyzetértékelésük folytán, félreértettek. Nem a vezető szaktudósok kívánják befolyásolni a szakmódszertan, a szakpedagógia egyik vagy másik irányzatának érvényesülését. Ma a vezető kutatók, az ELFT, a BJMT vagy az MTA azon legtekintélyesebb tanárok kérésére szólalnak meg, akik az elmúlt évtizedben kiszorultak a természettudományi közoktatás irányát meghatározó állami testületekből, szakértöi bizottságokból.

Világos bizonyíték az OKNT tavalyi vizsgálódását követően a középiskolákban használtak alternatíváját jelentő természettudományi tantervek megalkotására kiírt pályázat alakulása. A két kidolgozott tantervet megalkotó csapat az Eötvös Loránd Fizikai Társulat, illetve az ELTE TTK köré tömörült. Mindkét csapatban feltüntek azok a legnagyobb tekintélyü tanárszemélyiségek, akik már egy évtizede semmiféle hasonló munkában nem vállaltak szerepet.

A közösségi azonosulás továbböröklődik a természettudományi tanárpálya utánpótlására is. Az ebből fakadó második peremfeltételt szeretném alább megvilágítani.

A pedagógusi pálya széles spektrumú tevékenységi köréhez sokféle késztetés vonzhatja a középiskolásokat. Egyetemi oktatóként hosszú évtizedek óta szerzett, a természettudományi szaktanárokra vonatkozó tapasztalataim eredője egyértelmü: Kizárólag a szaktanári példa ösztönözte a jelentkezőket. A tudományos szakismeretek továbbadását szolgáló készségeiket aztán iskolájuk szakkörébe visszajáró előadóként, nyári táborokban szenior diákvezetőként, a tehetséggondozó diáklapoknál feladatjavítóként, versenyszervezőként tökéletesítették. Éppen a Bolyai Kollégium diákjaitól tudtam meg, hogy nő azok száma, akik karitatív csoportok tagjaiként szociális munkát vállalnak, hátrányos helyzetü gyerekekkel foglalkoznak (pl. Pósa-tábor). Itt szereznek szélesebben értelmezhető nevelési tapasztalatokat, és kezdik felismerni az általános pedagógia eszköztárának a szakismeretekkel egyenrangú fontosságát. 
A pedagógusi hivatásérzet kialakulásához vezető út szakaszai azonban nem cserélhetők fel. Az a bevezető pedagógiai képzési kínálat, amely teljesen független, sőt idegen a szakterületi érdeklődéstől, elriasztó hatású.

Korábban az önálló tanárszakokat többen azért választották, mert a középiskolai tehetségkutató rendszerben sikeresebb társaik teljesítményéhez mérve magukat, a kutatószakok követelményeit nem merték vállalni. Mások az egyetemen értik meg, hogy nem az új ismeretek apró lépésekből álló, hangyaszorgalmú gyarapítására, hanem a tudomány lenyügöző építményének bemutatására van tehetségük. A valós hajlamokat felszínre hozó első egyetemi évek során mindig jelentős a mozgás a tanár- és a kutatószakok között.

Az egységes alapszak elvben megkönnyítheti a kibontakozó képességek és változó hajlamok szerinti váltást, ezért (szemben a Bolyai Mühelykonferenciákon sokak által megfogalmazott nézettel) én továbbra is elvárom a tanári és a nemtanári szakok közötti kétirányú átjárás biztosítását az alap- és a mesterszak váltásakor. Ennek a követelménynek sem a 3+2 éves rendszer eddigi gyakorlata, sem az egységes ötéves képzéshez történő visszatérésre eddig megismert elképzelések nem tesznek eleget.

A „Bologna-rendszer” sommás hibáztatása ugyanolyan hiba, mint odébbtolni a tanárképzésnek a „Bologna-rendszerrel” egyidejűleg bevezetett új modellje kritikai vizsgálatát, annak koraiságát hangoztatva. A hiba szerintem nem a „Bolognarendszerben", hanem a tanárképzés hazánkban(!) kialakított rendszerén belül az általános pedagógia és a szakpedagógia szembeállításig fajult elkülönítésében van!

\section{Természetismeret és természettudomány a társadalmat átfogó közoktatásban}

(Szakkörök, versenyek hagyománya; Csodapaloták és a természettudományi kommunikáció új lehetőségei)

A természet ismeretének érzelmi nevelést is szolgáló, a tudomány müvelésére ösztönzésnél jóval szélesebb hatásának felismerése fogalmaztathatta meg Comenius-szal „Pictus Orbis”-a ajánló sorait: „Adattassék a' Gyermekek' kezeikbe, hadd gyönyörködtessék magokat a' Képeknek meg-nézésével kedvek szerint, hogy azokat vóltaképpen meg-ismerhessék, még otthon-is, minekelõtte az Oskolában el-kûldettetnének".

A tudományos elvekre épülö, hatékony, sokféle emberi igényt kiszolgáló mesterséges környezet megismerése legalább megduplázza a feladatot. Ezért nem korlátozódhat a természettudomány és a mérnöki tudományok felé orientáló nevelés azokra az arányaiban kishányadú diákcsoportokra, akik felsőfokú szakmai képesítést kívánnak szerezni ezen a területen. A széles társadalmi közvetítés igénye a hagyományos szaktanári feladatkört tovább differenciálja. A tudomány látványos és vonzó kommunikálásának szakmája elválik a rendszeres ismeret és a tudatos hasz- 
nálat alapjait nyújtó iskolai oktatásétól. Kétségtelen, hogy speciális megközelítésre van szükség a természetet a tudományos módszerrel (Descartes) értelmező, kutató, hasznosító pályákra készülőknek, akiknek szakmai kötelessége a folyamatos kétkedés és kritika. Egyre többet és megfontoltabbat kell nyújtani a természet mély ismeretének elvontsága miatt a részletektől tartózkodó (félő), egyetlen biztos, nagy igazságban reményt kereső többségnek (Pascal).

A magyar természettudományi tehetséggondozás hagyománya az első csoportra építi kiválóságképét. A híres versenyhagyományok néhány tucat iskolát mozgatnak a mai napig. Az ELTE TTK által javaslatomra tavaly először kiosztott „A természettudomány kiváló iskolája" cím odaítélése kapcsán megnéztük, hogy 20062009. években mely középiskolákból felvételiztek sikeresen karunkra. Azoknak a középiskoláknak a száma, amelyek a TTK-ra ez időszak alatt összesen 10-nél több diákot küldtek kevesebb, mint 70.

Úgy vélem, hogy a természettudományi karok országos holdudvara nem nagyobb 100-120 iskolánál. Ezek az iskolák küldik tanulmányi versenyekre diákjaikat, ezen iskolák egy részében maradtak meg a szakkörök, itt vállalják a felkészítést emeltszintü természettudományi érettségi vizsgákra. Az itt tanító tanárok legjobbjai felelnek meg a klasszikus „tudós tanár” képnek.

A modern demokratikus iskolarendszer a tudományos megalapozottságú civilizációban önbizalomteli mozgásra képes fiatalok körét kívánja tágítani. Az értetlenül szemlélt világ bénultságot, vagy ami még rosszabb: hamis megváltók követését eredményezi. A közoktatás kiszélesedése a tanári kiválóság új jegyeinek megjelenésével és elismerése iránti igénnyel jár. A kommunikációs készségek, a kvalitatív érvelés, az elvont helyett a konkrét érzékelhető valóságra hivatkozás képessége a szaktanári kiválóság újabb aspektusait tolják előtérbe. Ennek az irányzatnak is szakmaspecifikusan kell teret teremteni. Nincs szükség bármit eladni képes, önálló meggyőződés nélküli, az igazat mesterien leegyszerüsítőtől az eleve hamisat megkülönböztetni képtelen kommunikátorokra.

Sajnálatos tapasztalatom szerint a hazai pedagógia számos befolyásos személyisége támadja a nagyhagyományú tanári szerep kiváló személyiségeit az „elitizmus" vádjával. Érthetetlen és kártékony szenvedéllyel igyekeznek egyes pedagógiai szaktekintélyek a közoktatásbeli természettudományi tagozatok ellehetetlenítését elérni. Nevetséges érvekkel akadályozzák a természettudományi versenyek szélesebb körében az elért eredmények felvételi többletpontszámmal való elismerését. A szaktanári kiválóság új jegyei elismertetésének útja nem épülhet a hagyománnyá nemesedett értékek megsemmisítésére.

A természettudományos szaktanárok sokkal világosabban és befogadó szemlélettel látják az új kihívásokat és igyekeznek azokra is pozitív választ adni. $\mathrm{Az}$ Ericsson díjat két kategóriában adják ki. A versenyeredményekben megnyilvánuló tehetséggondozási kiválóság mellett a „fizika népszerüsítéséért” is jár ilyen díj. Ezt azután a fizikatörténet egy-egy jeles fordulópontjának dramatikus feldolgozásától 
természettudományi kapcsolódású túraverseny megszervezéséig terjedő spektrumban lehet elnyerni. Azt sem tekintem véletlennek, hogy fizika szaktanárok és nem általános neveléstudósok hozták létre az ország 4-5 müködő természettudományi Csodapalotáját. Ezek egyszerre helyettesíthetik az eszközök nagy tempóban emelkedő árát követni képtelen iskolai szertárakat és adnak lehetőséget a csúcstechnika barátságos játszótéri kipróbálásának.

A többfajta pedagógiai kiválóságot a szakmai körök nem egymás rovására érvényesülő, hanem egymást támogató rendszerelemekként ismerik el. Számomra érthetetlen a hagyományos kiválóság gyakorlatának mindenáron való megszakítására való ideológikus hátterü törekvés (,,a természettudományok intenzívebb tanítása sztálinista maradvány").

\section{Hogyan müködhetne?}

Szakmailag felkészült, emberileg vezetésre alkalmas személyek irányításával le kell küzdeni az általános és a szakpedagógia mesterséges, kizárólag a szervezeti terjeszkedést szolgáló szembeállítását! Ehhez a jelenlegi személyi vákuumban hasznát lehet venni némely tekintélyes szaktudósok közremúködésének, pl. a fizikában Tél Tamás, a matematikában Laczkovich Miklós szolgált rá a mindenirányú bizalomra.

A hazai szakpedagógiai teljesítmény nemzetközi összehasonlításból egyértelmüen kitủnő fejletlensége a szaktudományok (tehát a fizika szakmódszertana tekintetében a fizikusok) felelőssége. A rendszerváltás során az ideológiai átitatottságukkal elhíresült szakpedagógiai csoportokat megszüntettük, de egycsapásra másodrangúvá fokoztuk le a szakintézetek szakmódszertanosainak szerepét. Tehetséges tanárkollégáink korábban hagyományos egyetemi részfoglalkoztatását (fizikában: Vermes, Párkányi, Soós, Fözy) megszüntettük. Újra be kell vonni a legtekintélyesebb szaktanárokat az egyetemi szakpedagógiai (szakmódszertani) képzésbe!

Programot kell indítani a szakterületi doktori iskolák keretei között a gyakorlatban kiváló tanárok szaktudományi PhD-szerzésére nemzetközi színvonalú szakmódszertani alkotásaik alapján! Szakmódszertani docensi és professzori állásokat kell meghirdetni a TTK-kon, ha nem megy másként, akkor európai (lengyel, cseh, olasz, osztrák, német) szakemberekkel kell azokat betölteni! Alkalmassá kell tenni az egykori tanárképző főiskolák szaktanszékeit a BSc alapszak tanári szakirányú programjának megvalósítására. Ezek egyike sem rendelkezik ma elegendő szakmai erővel. A fejlődéshez kormányzati programra és a vezető egyetemek együttmüködésére van szükség! 